\title{
Digital Italy: Teacher Training as a Prerequisite for Economic Progress
}

D.L. Bearden

Master of Arts in Education Program

University of Roehampton London

Erasmus House, Roehampton Lane

London SW15 5PU, United Kingdom

dl.bearden@faculty.roehampton-online.com

ABSTRACT: Teaching and learning using digital technology is a concern to policy makers in Italy. All the European states are concerned about cognitonics in education. How will the emerging Digital Italy project affect emerging adults in the knowledge economy? What can be gained by expanding broadband capacity to all of Italy's school population and at what cost? Does the use of emerging technology improve human contact and does it create opportunity for youth employment after graduation? Will university enrollment increase? This paper provides a snapshot of the cyber readiness of Italy at the midpoint of deploying Digital Italy.

Keywords: Digital Italy, Digital Technology, Cyber Readiness

DOI: $10.6025 / \mathrm{ed} / 2019 / 8 / 1 / 10-16$

Received: 2 August 2018, Revised 7 October 2018, Accepted 20 October 2018

\section{(C) 2019 DLINE. All Rights Reserved}

\section{Introduction}

The Digital Agenda for Europe's 2020 Strategy defined the role of Information and Communication Technologies (ICT) [[18]]. For Italy and other EU members the strategy with five years to spare hit the targets of the Digital Agenda for Europe [[1], [2], 3]. Much of the success to date is within the private sector's race to provide the broadband infrastructure. The ultrawide band plan is now underway according to Lombardo [8].

Integration is the next demand. Education reform began in Italy in 2003. The National Service for the Evaluation of the Education and Training System (INVALSI) administers the assessments. The Ministry of Education [12] set out the competences for the evaluation of the school system, teachers and student achievement. A path was established for supplying schools with multimedia equipment, connecting schools to the Internet, setting up networks and services, and training teachers [6]. Teachers are familiar with ICT for teaching and learning but only use it to prepare to teach. Few students use technology for lessons or to communicate with parents $[3,7]$. The lack of a universal learning content management system (LCMS) is common at the public school level worldwide though there exist systems in Europe that are national in scope. The Italian government conforms to the Lisbon agenda on the information society [18].

\begin{tabular}{lllll}
\hline 10 & Electronic Devices Volume 8 & Number 1 & March 2019 \\
\hline
\end{tabular}




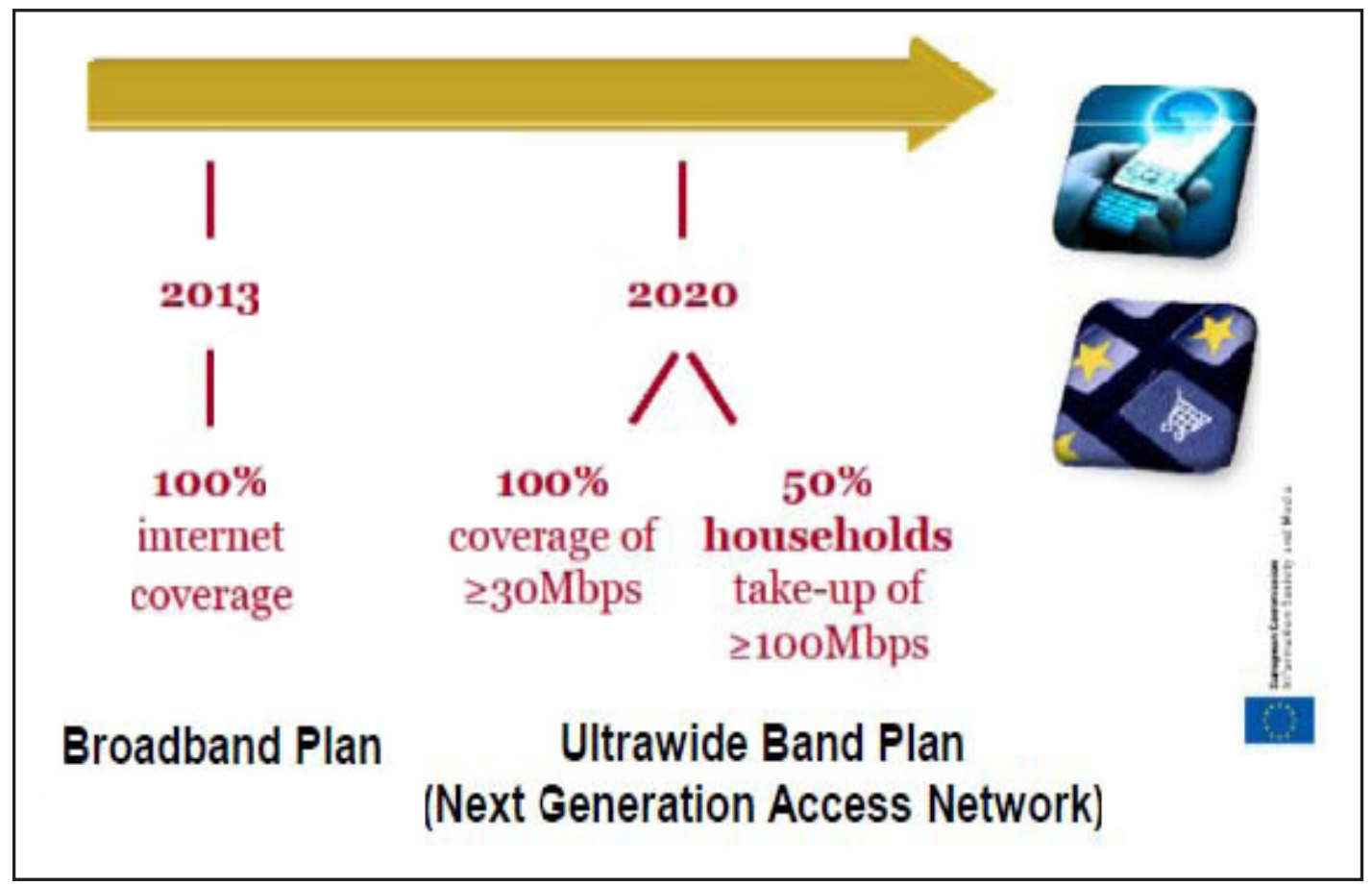

Figure 1. Broadband expansion [2013 Siva Project]

New educational opportunities provided by mobile applications are usually not seen by Italian teachers. The World Virtual School conducted a global survey of international schools [13] and found that internationally $74 \%$ of users used a cell phone to access the Internet. In fact, developing nations significantly exceeded European nations in numbers of mobile subscriptions: 3,846 to 741. Italy had slightly more than $50 \%$ broadband penetration with just above 4 milibits per second speeds. The US and France for example had over $75 \%$ penetration with $4.8 \mathrm{mbps}$ and 17.6 mbps speeds respectvely.

\section{Expansion and Austerity}

The Italian Minister for Economic Development Federica Guidi in 2014 said "Without an expansionary change and without abandoning austerity measures, Europe 2020 targets will become just unrealised dreams" [5]. Prime Minster Matteo Renzi: "We are not asking for flexibility in Europe, we are just taking what wne deserve" [4]. Using provison of the Internal Stability Pact, Renzi was able to unblock $43 €$ billion for infrastructure improvements in the regions where funds were present.

Government funds were leveraged with private sector funds to build the backbone of the Internet in Italy. The public funding provided the seed but the bulk of investment evolved toward the private side.

\section{Teaching and Learning}

MIUR promotes Piano Scuola Digitale - a platform to change learning environments through the integration of technology in education. The environments in which the school and students are immersed are rich in cultural stimuli but must overcome the fragmentation of knowledge and to integrate the disciplines in new perspectives. This requires transforming the learning environments, the language of school, work tools and content.

The Scuola Digitale [12] is the opportunity to overcome the traditional concept of class, to create a learning space open to the world in which to build a sense of citizenship and achieve "smart, sustainable and inclusive growth", the three priorities of Europe 2020. The first generation programs of the ministry of education through which the schools approached the use of ICT evolves today in a dimension of technology integrated into teaching. Not a class in the laboratory but in the laboratory there is class: a strategy of many actions [14]. 


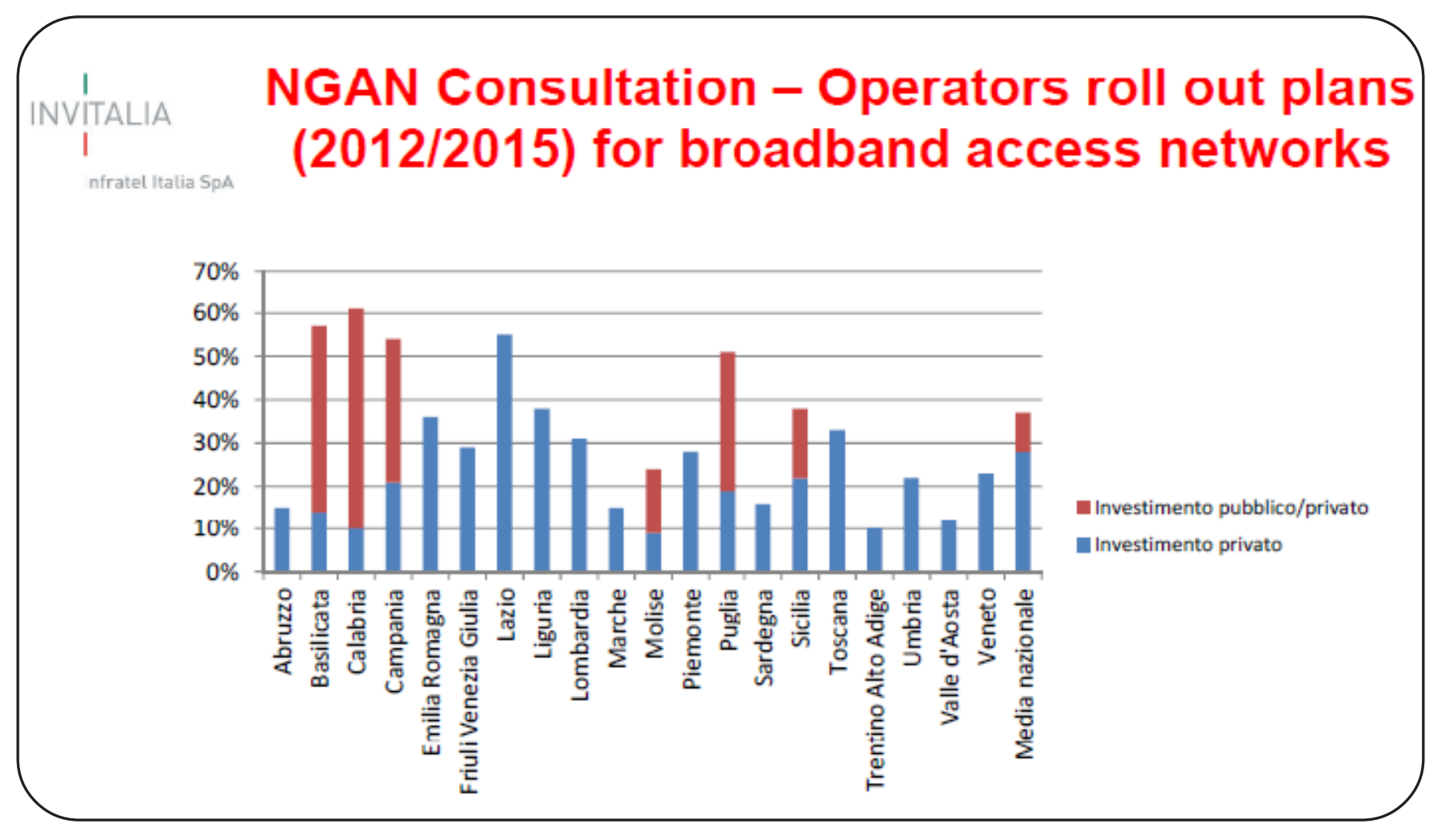

Figure 2. Public / Private finance [2013 Siva Project]

\subsection{Mortalita' Scolastica}

A high failure rate in the public school system may be attributed to both strong curriculum rigor and teacher incompetence [17]. The Investigation in Primary Education Teachers' Confidence and Competence Supporting Innovation (IPETCCO) studied ICTbased innovation among southern European primary school teachers. The central concern was with teachers'skills, knowledge and attitudes towards ICT and innovation [15].

The assumptions emerging from the literature were that teachers don't use ICT in practice and do not follow constructivist learning principles. Peralta and Costa [15] found that in the five southern European countries included in their research most primary teachers used ICT only as a supplement and not in the core content of their teaching.

This despite reporting they were knowledgeable of the tools of information technology. Italian teachers reported that ICT promotes collaborative work and gave great importance to technical competence. They did not agree that technical competence was sufficient without pedagogical and didactic interventions. The Italian teachers group selected for their innovation believed ICT is "a cognitive resource in learning allowing the development of more complex and richer thoughts" [15].

\subsection{Teacher Training}

The European Network for Innovative Schools (ENIS) uses the PuntoEdu platform to train teachers to use ICT in pedagogy. MIUR [4] introduced digital textbooks in 2011 and encourages the adoption of reusable learning objects in practice. The National Agency for the Support of School Autonomy (ANSAS) developed the following repositories of learning objects:

- Dia (http://www.indire.it/archivi/dia/)

- Gold (http://gold.indire.it/gold2/)

- Musicnet (http://www.indire.it/musiknet/)

12 Electronic Devices Volume 8 Number 1 March 2019




\begin{tabular}{|c|c|c|c|}
\hline Area & High & Mid & Low \\
\hline Initial Training & & $\square$ & \\
\hline Inservice & & $\square$ & \\
\hline Curriculum Development & & & $\nabla$ \\
\hline ICT based assessment & & & $\nabla$ \\
\hline Infrastructure & & $\nabla$ & \\
\hline Digital learning resoures & $\square$ & & \\
\hline School home connections & & & $\square$ \\
\hline ICT for special needs & & $\nabla$ & \\
\hline ICT research & & $\nabla$ & \\
\hline eSafety & & $\square$ & \\
\hline Reducing digital divide & & $\nabla$ & \\
\hline Interactive whiteboards & $\square$ & & \\
\hline Netbooks and notebooks & & & $\square$ \\
\hline Key competencies & & $\square$ & \\
\hline $21^{\text {st }}$ Century skills $\quad \square$ & & & \\
\hline
\end{tabular}

Table 1. Priorities for teachers surveyed in Italy[6]

\section{ICT and Employability}

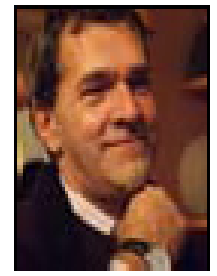

Carlo Fanara, $\mathrm{PhD}$, a data scientist and physics consultant from Turin Italy, worked as a curriculum designer and instructor in the European Union for several years. In a personal communication (2015) he commented regarding the prospects for young Italians seeking employment in the 21 st Century job market based on a lack of access to IT infrastructure during their years in the public school and university systems in Italy. "I think indeed that students facing problems may develop stronger solving skills with respect to students of countries or institutions better equipped in infrastructure in general (and IT in particular). One hopes that the infrastructure nevertheless does get better...” [[1]].

\subsection{Mobile Technology}

The Pew Research Center [[16]] conducted a study of mobile phone use in the developing world with surprising results. Despite lacking infrastructure that is present in Western developed countries of Europe and North America the use of mobile technology is ubiquitous. While Italy is certainly part of the West its Internet capacity historically was no better than the emerging nations studied by Pew.

Marzouki et al. proposed a mobile leaning model for institutions to take advantage of the private investment made in smart phones globally. “... mobile learning enhances the educational program and reinstates it into the daily lives of learners through their own mobile technologies," [10] (p. 1). Generation Y learners are those that are entering the work force and those that would be the most prepared to adopt mobile learning. In fact traditional learning is not sufficient to capture the talents of young learners and the skills that are acquired in face-to-face didactic learning does not prepare them for a workplace that is based in the knowledge economy. 
Et Tu Create [3] offers post-secondary certificate courses titled Mobile Application Design and Development. The courses include 18 constructivist learning modules that follow an introduction to careers, legal aspects, hardware, operating systems, design, quality control, monetization, marketing and programming.

The courses require the learner to download a 30-day free trial version of the AGK Basic App Development Kit (http:// www.appgamekit.com).

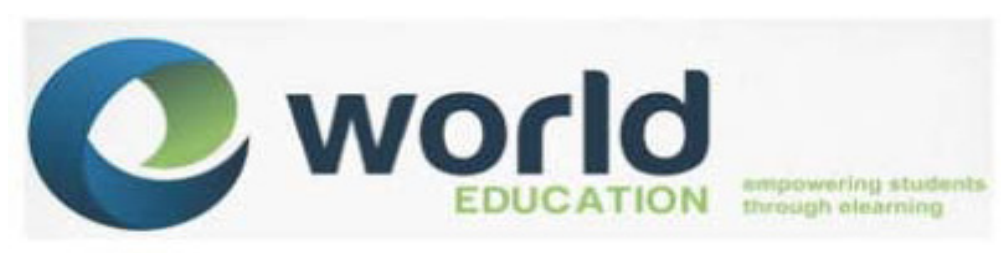

Figure 3. Et Tu Create $C$ logo

\begin{tabular}{|l|l|l|l|}
\hline Region & IWB & Students & Teachers \\
\hline ABRUZZ0 & 869 & 19.118 & 3.006 \\
BASILICATA & 516 & 11.352 & 1.221 \\
CALABRIA & 1.499 & 32.978 & 3.510 \\
CAMPANIA & 4.038 & 88.836 & 8.945 \\
EMILIA ROMAGANA & 2.217 & 48.774 & 5.395 \\
FRIULI-VENEZIGIULIA & 713 & 15.686 & 1.634 \\
LAZIO & 2.989 & 65.758 & 6.872 \\
LIGURIA & 795 & 17.490 & 1.897 \\
LOMBARDIA & 5.112 & 112.464 & 11.729 \\
MARCHE & 1.008 & 22.176 & 2.623 \\
MOLISE & 270 & 5.940 & 610 \\
PIEMONTE & 2.320 & 51.040 & 5.590 \\
PUGLIA & 2.687 & 59.114 & 6.089 \\
SARDEGNA & 1.021 & 22.452 & 2.435 \\
SICILIA & 3.545 & 77.990 & 8.464 \\
TOSCANA & 1.956 & 43.032 & 4.708 \\
UMBRIA & 535 & 11.770 & 1.333 \\
VENETO & 3.025 & 66.550 & 7.610 \\
TOTALE & 35.115 & 772.530 & 83.671 \\
\hline
\end{tabular}

Table 2. Whiteboard use [12]

Enrollment in the courses can be done through One World School (http://www.1worldschool.com), which uses a Moodle platform and is accessible globally.

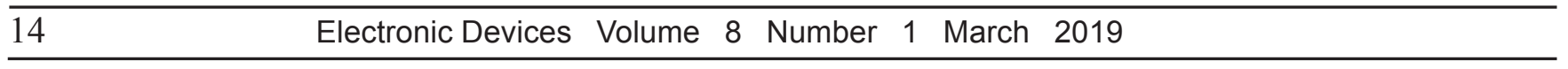




\section{Brick and Mortar Technology}

Given that Italian teachers have a low priority for computers in the classroom and a high propensity for white boards it is useful to see how this technology can be constructively utilized. A didactic approach to education can yield results if students are introduced to emerging technologies and then are given the opportunity to explore through mobile technology on their own time.

\section{Conclusion}

Teachers in Italian public schools are not inclined to allow use of mobile technology in their classrooms because they are not trained to profit from the personal investment made by families in emerging technology [17]. Teachers are open to using interactive whiteboards because of the didactic mode fostered [[9], [11]].

A truly Digital Italy will provide a psychological boost for youg adults in the knowledge economy. Expanding broadband capacity, though costly, will produce an economic boost to the struggling economy that is held back by EU austerity. Emerging technology, by improving human contact, creates opportunity for employment and tertiary learning.

\section{References}

[1] Clifton, J., Diaz-Fuentez, D., Fernandez Gutierrez, M. (2015). Public infrastructure services in the European Union: Challenges for territorial cohesion. 2015. Retrieved from http://www.researchgate.net/publication/275640620_Pu blic_infrastructure_services_in_the_European_Union_Challenges_for_territorial_cohesion_Forthcoming_in_2 015_in_Regional_Studies

[2] Digital Agenda for Europe. Survey of schools: ICT in education by European Schoolnet. Retrieved December 27, 2013, from http://ec.europa.eu/digitalagenda/ sites/digital-agenda/files/KK-31-13-401-ENN. pdf. 2013.

[3] Digital Agenda for Europe. Digital Agenda scoreboard (2015). Most targets reached, time has come to lift digital borders. Retrieved from http://ec.europa.eu/digitalagenda/. 2015.

[4] Et Tu Create LLC.(2013). Mobile Application Design and Development. Certification course post-secondary. 2013. Retrieved from http://www.1worldschool.com/course/view.php?id=697

[5] EU News(2014). With austerity, Europe 2020 targets will become just unrealized dreams. 2014. Retrieved from http:// www.eunews.it/en/2014/07/21/guidi-withausterity-europe-2020-targets-will-become-justunrealised-dreams/19785

[6] European Schoolnet. Country report on ICT in Education: Italy. 2011. Retrieved from http://www.eun.org/c/document_library/ get_file?uuid=a3bb5826-9585-4f0f-acc8-cea2d19f3bd4\&groupId=43887

[7] European Union. Treaty of Lisbon amending the Treaty on European Union and the Treaty establishing the European Community. Official Journal of the European Union C306/1, 17 December. 2007.

[8] Lombardo, S. (2013). Infratel Italia Spa. Italian broadband plan. Retrieved from sivaproject.eu/download.php?fen=entries/ 0153_1873.pdf

[9] Gaballini, P. (2008). Profiles of Italian urban planning. Plannum.net The European Journal of Planning, August.

[10] Marzouki, O. F., Retbi, A., Idrissi, M. K., Bennani, S. (2014). Mobile education: proposing a mobile learning model for designing an institutional mobile scenario. Research Journal of Applied Sciences, Engineering and Technology 7 (21).

[11] MEPI (2013). Mercato elettronico della pubblica istruzione. Retrieved from https:/www.acquistinretepa.it/opencms/opencms/ main/programma/servizi/Progetto_Scuole/

[12] MIUR. (2011). Italian Ministry of Education, University and Research. Piano Scuola Digitale. Retrieved from http:// hubmiur.pubblica.istruzione.it/web/istruzione/dettaglio-news/-/dettaglioNews/viewDettaglio/28385/11210

[13] Muir, D. (2010). International Schools Needs Assessment Survey http://www.world-virtualschool. com/abstract.pdf. 2010.

[14] Nazzaro, A. (2013). The Italian national plan for digital school in the framework for Digital Agenda for Europe. Rome: Register of Industrial Research.2013.

Electronic Devices $\quad$ Volume 8 Number 1 March $2019 \quad 15$ 
[15] Peralta, H., Costa, F. A. (2007). Teacher competence and confidence regarding the use of ICT. Educational Sciences Journal 3 (May-Aug).

[16] Pew Research Center. (2014). Emerging nations embrace internet, mobile technology: Cell phones nearly ubiquitous in many countries. Retrieved from http://www.pewglobal.org/2014/02/13/emergingnations- embrace-internet-mobile-technology/

[17] D. Straughan. School mortality in Italy [blogpost] Retrieved from http://www.beginningwithi.com/?s=School+mortality+in+Italy. 2004.

[18] VISCED (2012). Researching virtual initiatives in Education. Retrieved from http://www.virtualschoolsandcolleges.eu/index.php/ Cat egory:Virtual_schools_in_Europe.2012. 